\title{
INCREASING COMPANY PERFORMANCE WITH LIQUIDITY, SOLVENCY IN CIGARETTE INDUSTRYLISTED IN IDX
}

\author{
Suprihati ${ }^{1)}$ Abdul Haris. ${ }^{2)}$ Gita Wahyu.A.M ${ }^{3)}$ \\ STIE-AAS Surakarta, Central Java, Indonesia \\ Suprihati4566@gmail.com
}

\begin{abstract}
In this study aims analyze the effect of financial ratios on the performance of cigarette companies listed on the IDX. The factors tested in this study are the effect of liquidity ratios, solvency ratios and activity ratios as independent variables while the company's profitability as the dependent variable.

The sample in this study were all populations consisting of four companies and the data used are secondary data. The analytical tool used is multiple linear regression analysis at a significance level of 5\%, with the regression equation $\mathrm{Y}=0.180+0.006 \mathrm{X} 1-0.014 \mathrm{X} 2+0.090 \mathrm{X} 3$.

In this study the influence of pritability is activity while liquidity and solvency do not affect profitability. And simultaneously obtained Fcount 5.381 is greater than $F_{\text {table }} 2.89$ with a significance of 0.004 smaller than the significance value of $\alpha=0.05$, this shows that simultaneously Liquidity, Solvability and Activity are factors that influence profitability.
\end{abstract}

Keywords $\quad$ : Profitability, Liquidity, Solvability, Activity

\section{Background}

According to Harahap (2013: 18) the objectives of financial statements are: (a) Screening, analysis is carried out with the aim of knowing the situation and condition of damage from the financial statements without going directly to the field, (b) Understanding, understanding the company, financial condition, and the results of its business, (c) Forecasting, analysis is used to predict the company's financial condition in the future, (d) Diagnosis, analysis is intended to see the possibility of problems that occur both in management, operations, finance, or other problems in the company, (e ) Evalution, analysis is carried out to assess management's performance in managing the company.

According to Fahmi (2011: 5) the purpose of the financial statements is to provide financial information that includes changes from the elements of financial statements that are shown to other parties who have an interest in evaluating the financial performance of the company in addition to the company management.

Types of financial ratios according to Martono and Harjito (2010: 53) in general there are 4 types of ratios that can be used 


\section{Vol-2, Issue-2, 2018 (IJEBAR)}

ISSN: 2614-1280, http://www.jurnal.stie-aas/ijebar

to assess the company's financial performance, namely: Liquidity ratio that is the ratio that shows the relationship between the company's cash and other current assets with current debt. Liquidity ratios are used to measure company's ability to meet its financial obligations that must be met immediately or short-term liabilities. Some Liquidity Ratios are: (1) Current ratio is the ratio between current assets and currentliabilities. A high current ratio gives an indication of a good guarantee for short-term creditors in the sense that every time the company has the ability to pay off its short-term financial obligations. However, a high current ratio will negatively affect the ability to obtain profit (profitability), because some working capital will not spin or experience unemployment.

(2). Quick Ratio A more accurate measurement tool to measure the level of company liquidity is a quick ratio. This ratio is a balance between the amount of current assets less inventory and the amount of current debt. Quick ratio focuses the components of current assets that are more liquid, namely: cash, securities, and receivables associated with current debt or short-term debt.

Solvability Ratio is a ratio that measures how many companies use funds from debt (loans).

Some Solvability Ratios are: (1) Debt ratio (debt ratio) is the ratio between debt (total debt) and total assets (total assets) expressed in percentage. The debt ratio measures what percentage of the company's assets are spent with debt. (2) Total Debt to Equity Ratio The total debt to equity ratio (ratio of total debt to equity) the ratio of total debt to equity is the ratio of total debt owned by the company to its own capital (equity). 3) Activity ratio, which measures the extent of the effectiveness of the company's management in managing its assets. The meaning in this case is to measure the ability of the management of the company in managing inventory of raw materials, goods in process, and finished goods and management policies in managing other assets and marketing policies. The activity ratio analyzes the relationship between profit and loss statements, especially sales, with elements that are in the balance sheet, especially elements of assets.

Some Activity Ratios are: (1) Total asset turn over (TATO) measures the turnover of all assets owned by a company. Total asset turnover is calculated from the division between sales and total assets. (1) Fixed Asset Turn Over This is the ratio used to measure how many times the funds invested in fixed assets rotate in one period. Or in other words, to measure whether the company has used the fixed assets capacity fully or not (Kasmir, 2013: 172). The ability of a company to make a profit in relation to total assets and equity sales. From this definition it is clear that the target to be sought is company profits (G. Sugiyarso and F Winarni (2005: 118) Profitability that is used as an assessment criteria for the results of operations of the company has very important benefits and can be used as follows: (1) Analysis the ability to generate profits to detect the cause of profit or loss generated by an information object in a certain period (2) Profitability can be used to describe the criteria that are needed in assessing the 
International Journal of Economics, Business and Accounting Research (IJEBAR)

Peer Reviewed - International Journal

Vol-2, Issue-2, 2018 (IJEBAR)

ISSN: 2614-1280, http://www.jurnal.stie-aas/ijebar

success of a company in terms of capability and motivation of management (3) Profitability is a tool for projecting a tool to make a profit projection of a company because it describes the correlation between earnings and the amount of capital invested.

\section{Method and Data Analysis}

In the data analysis technique, what is used in this research is a quantitative method, namely data analysis that uses numbers into ratio analysis to compare the financial performance of one company to another. The data analysis technique used in the study is by analyzing the financial ratios used as follows:

Liquidity ratio, which includes:

$$
\text { Current ratio }=\frac{\text { Current Asset }}{\text { Current liabilities }} \times 100 \%
$$

$$
\text { Quick ratio }=\frac{\text { Current Asset - Stock }}{\text { Current Liabilities }} \times 100 \%
$$

Solvency ratio, which includes:

Dept To Total Asset Ratio $=\frac{\text { Total Amoun of debt }}{\text { Total assets }} \times 100 \%$

Dept To Total Quick Ratio $=\frac{\text { Total Amoun of debt }}{\text { Total Capital }} \times 100 \%$

Activity Ratio, which includes:

\begin{tabular}{l} 
Total Asset Turn Over $=\frac{\text { Sales }}{\text { Total Aktiva }} \times 100 \%$ \\
Fixed Asset Turn Over $=\frac{\text { Penjualan }}{\text { Total Aktiva Tetap }} \times 100 \%$ \\
\hline
\end{tabular}




\section{Vol-2, Issue-2, 2018 (IJEBAR)}

ISSN: 2614-1280, http://www.jurnal.stie-aas/ijebar

Measurement of the company's financial performance by using time series analysis is an analysis carried out by comparing the financial ratios of companies from one period to another. Statistical analysis of descriptive data is used to describe the characteristics of the data from the sample in the form of mean, minimum, maximum, and standard deviation. In this study, the sample used was 36 samples of manufacturing companies in the cigarette sector listed on the Indonesia Stock Exchange in 20162018.

The results of descriptive statistical analysis are presented in table 1 as follows:

Table 1

\section{Descriptive Statistics}

\section{Descriptive Statistics}

\begin{tabular}{|l|l|l|l|l|l|}
\hline & N & Minimum & Maximum & Mean & $\begin{array}{l}\text { Std. } \\
\text { Deviation }\end{array}$ \\
\hline CR & 36 & 19 & 535 & 276,47 & 132,118 \\
DAR & 36 & 2 & 129 & 31,08 & 25,956 \\
TATO & 36 & 3 & 229 & 80,97 & 56,441 \\
ROA & 36 & 1 & 39 & 8,75 & 9,144 \\
Valid N & 36 & & & & \\
\hline
\end{tabular}

To measure the company's ability to meet short-term financial obligations. The minimum value of the liquidity ratio is spread 19 and the maximum value is $\mathbf{5 3 5 .}$ While the mean value of the liquidity ratio is 276.47 and the standard deviation of the liquidity ratio is 132,118 .

To measure how many companies use funds from debt (loans). The minimum value of the solvency ratio is spread 2 and the maximum value is 129 . While the mean value of the solvency ratio is 31.08 and the standard deviation of the solvency ratio is 25.956 .

A ratio to measure how effective a company is in operating its funds (assets).
The minimum value of the activity ratio is 3 and the maximum value is 229 . While the mean value of the activity ratio is 80.97 and the standard deviation of the activity ratio is $\mathbf{5 6 . 4 4 4}$.

It is an important measure to assess whether a company is healthy or not that affects investors to make decisions. The minimum value of the profitability ratio is 1 and the maximum value is 39 . While the mean value of the profitability ratio is 8.75 and the standard deviation of the profitability ratio is 9,144 . 
International Journal of Economics, Business and Accounting Research (IJEBAR)

Peer Reviewed - International Journal

Vol-2, Issue-2, 2018 (IJEBAR)

ISSN: 2614-1280, http://www.jurnal.stie-aas/ijebar

\section{Result and Discussion}

The classical assumption test is done to find out the existing data conditions in order to determine the right analysis model to use. The classic assumption test in this study consisted of Kolmogorof-Smirnov test to test the normality of data statistically, heteroscedasticity test using Scatteplot diagram method, multicollinearity test using VIF (Variance
Inflation Factors), and autocorrelation test using Durbin-Watson. (1) Normality test is used to find out that each variable has a normal distribution. In this study Kolmogorof-Smirnov test was used. Data normality test can be seen in the significance value or probability, if sig> 0.05 . The results of normality testing can be seen in the table below:

\section{One-Sample Kolmogorov-Smirnov Test}

\begin{tabular}{|ll|l|}
\hline & & Unstandardized Residual \\
\hline $\mathrm{N}$ & & 36 \\
Normal & Mean & 0,0000000 \\
Parameters ${ }^{\mathrm{a}, \mathrm{b}}$ & Std. Deviation & 7,45538493 \\
Most Extreme & Absolute & 0,207 \\
Differences & Positive & 0,207 \\
& Negative & $-0,168$ \\
Kolmogorov-Smirnov Z & 1,243 \\
Asymp. Sig. (2-tailed) & 0,091 \\
\hline
\end{tabular}

From the above table shows that the Kolmogorof-Smirnov value is 1.243 and a significance value of 0.091 is greater than 0.05 which means that the residual data is normally distributed and to see a more reliable method is to look at the normal probability plot that compares the cumulative distribution of the actual distribution with the cumulative distribution of the normal distribution. 
International Journal of Economics, Business and Accounting Research (IJEBAR)

Peer Reviewed - International Journal

Vol-2, Issue-2, 2018 (IJEBAR)

ISSN: 2614-1280, http://www.jurnal.stie-aas/ijebar

Table 3

Results and Multicollinearity Test

\begin{tabular}{|l|l|l|l|l|}
\hline Model & Variabel & \multicolumn{2}{|l|}{ Collinierity Statistic } & Conclusion \\
\cline { 3 - 4 } & Dependent & Tolerance & VIF & \\
\hline & CR & 0,770 & 1,299 & Non-Multicollinearity \\
& DAR & 0,782 & 1,279 & Non-Multicollinearity \\
& TATO & 0,982 & 1,018 & Non-Multicollinearity \\
& & & & \\
\hline
\end{tabular}

$\mathrm{R}$ with a VIF value of 1.299 less than the value of VIF 10 and tolerance value of 0.770 is greater than the minimum tolerance value of 0.10 , there is no multicollinearity. DAR with a VIF value of 1,279 less than the value of VIF 10 and the tolerance value of 0.072 is greater than the minimum tolerance value of 0.10 , so there is no multicollinearity. TATO with a VIF value of 1.018 less than the value of VIF 10 and the tolerance value of 0.982 is greater than the minimum tolerance value of 0.10 then there is no multicollinearity.

Autocorrelation test aims to test whether in the linear regression model

Table 4

Autocorrelation Test Data Results

Model Summary ${ }^{b}$

\begin{tabular}{|l|l|l|l|l|}
\hline Model & $\mathrm{R}$ & R Square & $\begin{array}{l}\text { Adjusted R } \\
\text { Square }\end{array}$ & Durbin-Watson \\
\hline 1 & $0,579^{\mathrm{a}}$ & 0,335 & 0,273 & 2,061 \\
\hline
\end{tabular}

By using the degree of error $(\alpha)=5 \%$ with a predictor of 3 , the upper limit (U) is 1.6539 while the lower limit (L) is 1.2953 because the DW value of regression results is 2.061 which means the value $\mathrm{dl}<\mathrm{dw}<$ there is a correlation between the error period $\mathrm{t}$ with the interruption period $\mathrm{t}-1$ (previous). If there is a correlation, then there is an autocorrelation problem. Autocorrelation arises due to successive observations over time related to each other. Autocorrelation testing is done by calculating the Durbin-Watson (DW) statistical value. The DW value is then compared with the Durbin-Watson critical value to determine its significance. 


\section{Vol-2, Issue-2, 2018 (IJEBAR)}

ISSN: 2614-1280, http://www.jurnal.stie-aas/ijebar

autocorrelation problem can be accepted, while the null hypothesis which states that there is autocorrelation can be rejected.

Heteroscedasticity test aims to test whether the regression model occurs variance inequality from residual one observation to another observation.

A good regression model is heteroscedasticity or no heteroscedasticity. One way to detect the presence or absence of heterocedasticity is by using the Glejser
Test method. From the Scatterplots graph, it can be seen that the points spread randomly and spread both above and below the number 0 on the $\mathrm{Y}$ axis, it can be concluded that there is no heterocedasticity in the regression model, so that the regression model deserves to be predicted to predict Liquidity (CR), Solvability (DAR) and Activities (TATO).

Table 5

\section{Heteroscedasticity Test results}

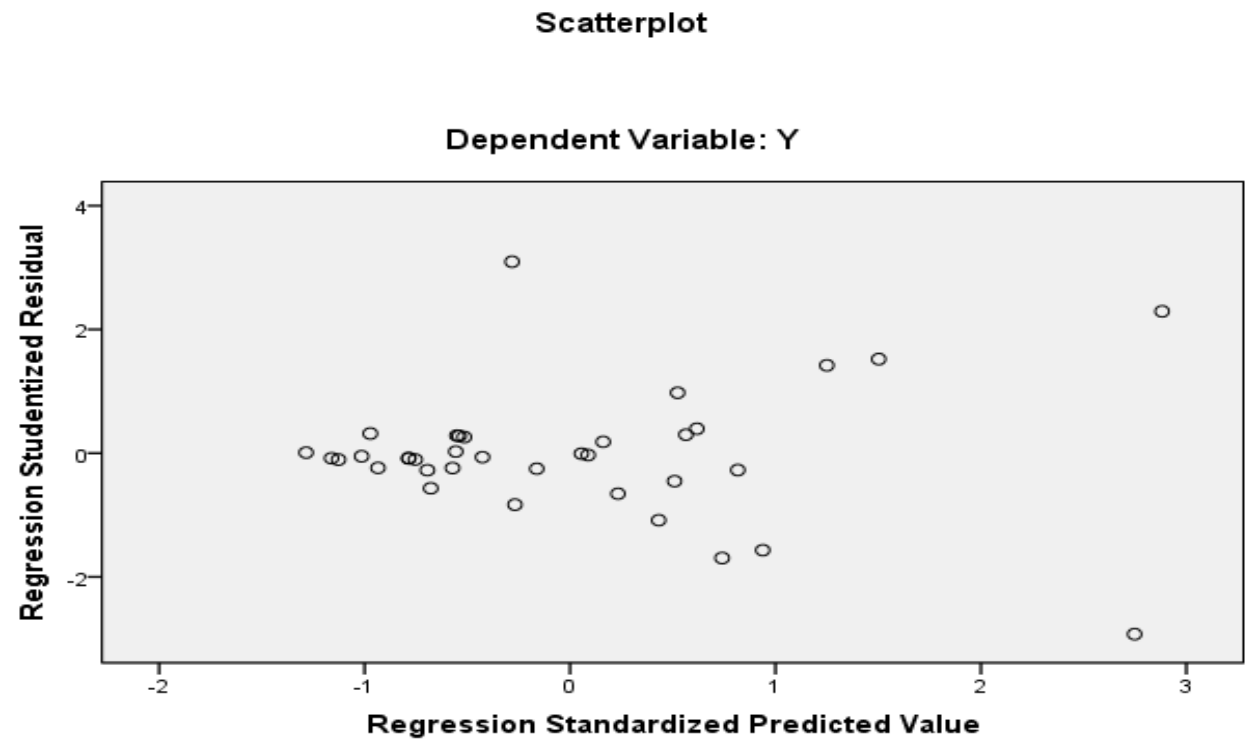

\section{Hypothesis Testing}

This analysis is used to determine whether the effects of Liquidity (CR), Solvability (DAR), and Activity (TATO) on Profitability (ROA). The results of data processing with the help of the SPSS version 20 program are obtained by the regression equation. The results of multiple regression tests can be briefly seen in the following table: 
International Journal of Economics, Business and Accounting Research (IJEBAR)

Peer Reviewed - International Journal

Vol-2, Issue-2, 2018 (IJEBAR)

ISSN: 2614-1280, http://www.jurnal.stie-aas/ijebar

Table 6

Multiple Linear Regression Data

\section{Coefficients $^{\mathrm{a}}$}

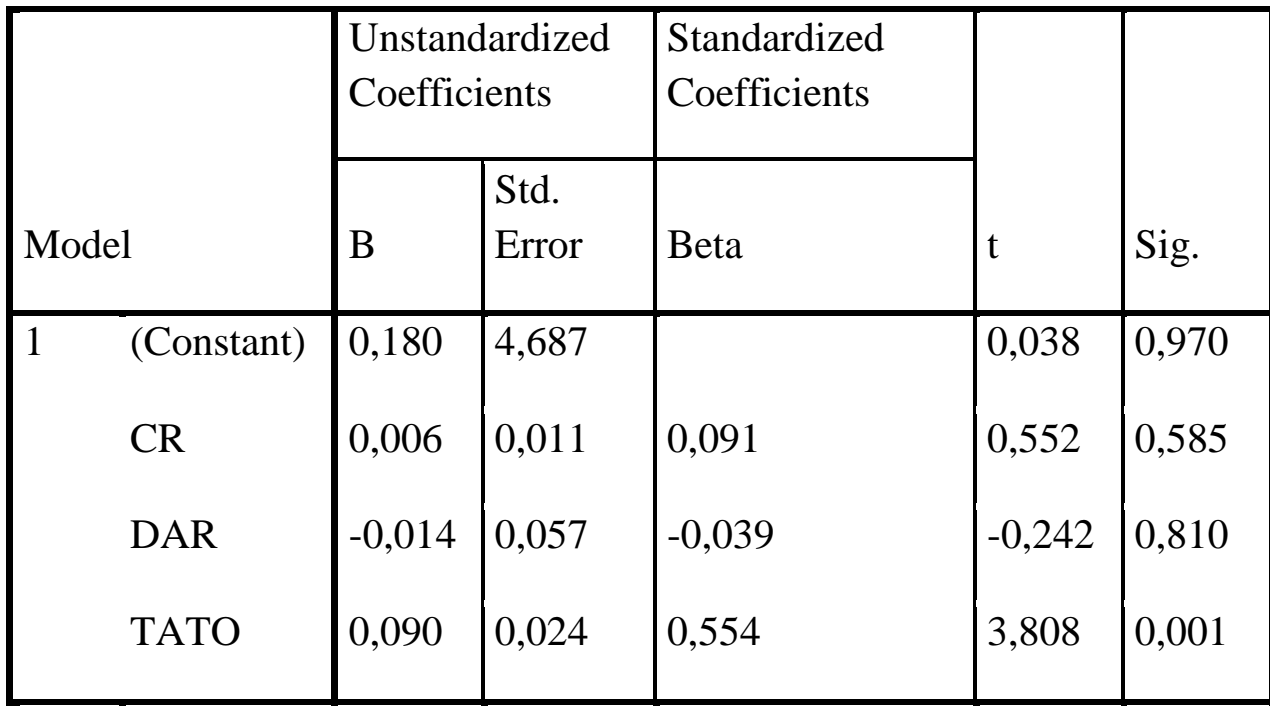

Based on the results of multiple linear regression which is examined in the variables Liquidity $\left(\mathrm{X}_{1}\right)$, Solvability $\left(\mathrm{X}_{2}\right)$, Activity $\left(\mathrm{X}_{3}\right)$, and Profitability $(\mathrm{Y})$ can be described as follows: $\mathrm{Y}=0.180+0.006 \mathrm{X} 1$ $-0.014 X 2+0.090 X 3$

Based on the calculation of multiple linear equations above shows that:

The constant coefficient of 0.180 means that if liquidity $\left(\mathrm{X}_{1}\right)$, solvency $\left(\mathrm{X}_{2}\right)$, activity $\left(\mathrm{X}_{3}\right)$, and profitability $(\mathrm{Y})$ is 0.180 . This shows that if the independent variable consists of liquidity $\left(\mathrm{X}_{1}\right)$ : 0.006 solvability $\left(\mathrm{X}_{2}\right):-0.014$ activity $\left(\mathrm{X}_{3}\right): 0.090$, and income smoothing $(\mathrm{Y}): 0.180$. Then the size of the dependent variable is income smoothing (Y) of 0.180 .

a. The liquidity coefficient $\left(\mathrm{X}_{1}\right)$ is 0.006 means that if the liquidity value $\left(\mathrm{X}_{1}\right)$ increases by 1 point, the movement of profitability will increase by 0.006 .

b. The solvency coefficient $\left(\mathrm{X}_{2}\right)$ is 0.014 means that if the liquidity value
$\left(\mathrm{X}_{2}\right)$ increases by 1 point, the movement of profitability will decrease by -0.014 .

c. The activity coefficient $\left(\mathrm{X}_{3}\right)$ is 0.090 means that if the activity value $\left(\mathrm{X}_{3}\right)$ increases by 1 point then the profitability movement will increase by 0.090 .

\section{Discussion}

To find out whether there is an influence of Liquidity (CR), Solvability (DAR), and Activity (TATO) on Profitability (ROA) an analysis is done by using $t$ test and test

$\mathrm{T}$ test is a test that is used to detect how well the independent variable can explain the independent variable individually. In this $t$ test aims to determine the effect of partially independent variables on the dependent variable, in this test is done by comparing the counts of each regression coefficient 
International Journal of Economics, Business and Accounting Research (IJEBAR)

Peer Reviewed - International Journal

Vol-2, Issue-2, 2018 (IJEBAR)

ISSN: 2614-1280, http://www.jurnal.stie-aas/ijebar

with the ttable value with the significant used (Astuti, 2014: 63). For the confidence level used is $95 \%$ or $\alpha=5 \%$. So $\mathrm{n}=36$ and $\mathrm{k}=4$ degrees of freedom (df): $36-4=$
32 , then the $\mathrm{t}$ table obtained is 2,03693 . $\mathrm{T}$ test results can be seen in table 4.9 as follows:

Table 4.10

\section{Coefficients $^{\mathrm{a}}$}

\section{T Test Result}

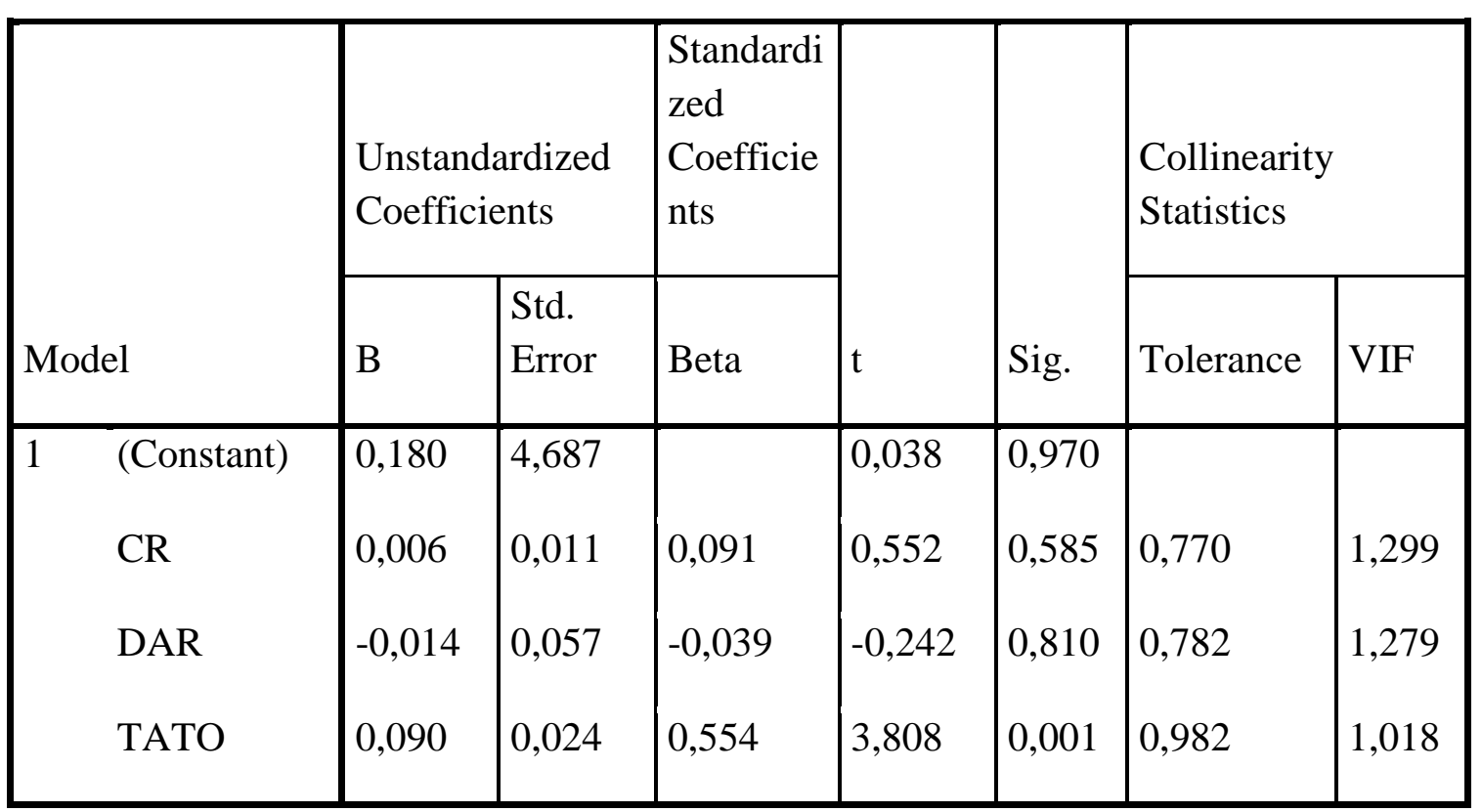




\section{Vol-2, Issue-2, 2018 (IJEBAR)}

ISSN: 2614-1280, http://www.jurnal.stie-aas/ijebar

From the regression results, it is known that the value of $t$ count Liquidity (CR) variable is 0.552 smaller than ttable 2.03693. With a significance value of 0.585 greater than $\alpha=0.05$. H1 means that Ho is rejected, this indicates that the Liquidity (CR) variable has no significant effect on Profitability (ROA).

From the regression results it is known that the value of tcount Solvability (DAR) variable is -0.224 less than $t$ table 2.03693 . with a significance value of 0.810 smaller than $\alpha=0.05$. H2 means that Ho is rejected, this indicates that the Solvability (DAR) variable has no significant effect on Profitability (ROA).

From the results of the regression it is known that the value of the activity variable tcount (TATO) of 3.808 is greater than the ttable of 2.03693. With a significant value of 0.001 smaller than $\alpha=$ 0.05. H3 means that Ho is accepted, this

Based on the data generated from table 4 the calculations obtained $F_{\text {count }}$ of 5.381 is greater than $F_{\text {table }} 2.89$ with a significance of 0.004 smaller than the significance value of $\alpha=0.05$, so it can be concluded that simultaneously or together the Liquidity (CR) variable, Solvability (DAR), and Activity (TATO) is a factor that influences the Profitability (ROA) shows that the Activity variable (TATO) has a significant effect on Profitability (ROA).

Test $\mathrm{F}$ is a test that tests all independent variables that show whether all the independent variables included in the model have a joint effect on the dependent variable. In this test aims to compare significant values $(\alpha=5 \%)$ at the level of $5 \%$. Decision criteria follow the following rules (Astuti, 2014: 63). In this $F$ test to calculate Ftable can be formulated with k; $\mathrm{n}-\mathrm{k}$, where $\mathrm{k}=$ number of independent variables (free) and $\mathrm{n}=$ number of respondents or research samples. Thus $\mathrm{k}=$ 3 Liquidity (CR), Solvability (DAR), and Activity (TATO) and $n=36$. Then we enter this value into the formula, then generate numbers $(3 ; 36-3)=(3 ; 33)$, then we make this reference to find out the Ftable value in the statistical Ftable value distribution. The F Test results can be seen in table 4.11 as follows:

variable of the $F$ can be seen that the regression model used in this study shows the goodness of fit model.

Determinant coefficient $\left(\mathrm{R}^{2}\right)$ essentially measures how far the ability of the model to represent the variation of the dependent variable. The value of the coefficient of determination is between zero and one. 
ISSN: 2614-1280, http://www.jurnal.stie-aas/ijebar

\section{Table}

\section{Determination Test data results $\left(\mathbf{R}^{2}\right)$}

\section{Model Summary}

\begin{tabular}{|l|l|l|l|l|}
\hline Model & $R$ & R Square & $\begin{array}{l}\text { Adjusted R } \\
\text { Square }\end{array}$ & $\begin{array}{l}\text { Std. Error of the } \\
\text { Estimate }\end{array}$ \\
\hline 1 & $0,579^{\mathrm{a}}$ & 0,335 & 0,273 & 7,797 \\
\hline
\end{tabular}

The calculation results for $\left(\mathrm{R}^{2}\right)$ are obtained by the adjusted coefficient of determination - $\mathrm{R}^{2}$ of 0.273 . This means that $27.3 \%$ variation in profitability variable (ROA) can be explained by the variables Liquidity (CR), Solvability (DAR), and Activity (TATO) while the remaining $72.7 \%$ is explained by other factors outside the model under study.

\section{Effect of liquidity ratios on financial performance}

The Liquidity Ratio (CR) has no effect on the Profitability (ROA) of the cigarette sector companies listed on the IDX. From the regression results, it is known that the value of $t_{\text {count }}$ Liquidity (CR) variable is 0.552 smaller than $t_{\text {table }} 2.03693$. With a significance value of 0.585 greater than $\alpha$ $=0.05 . \mathrm{H}_{1}$ means that $\mathrm{H}_{\mathrm{o}}$ is rejected, this indicates that the Liquidity (CR) variable has no significant effect on Profitability (ROA). This result is in line with research conducted by Hendry Andres Maith (2013) which states that the liquidity ratio (CR) has no significant effect on profitability (ROA).

\section{Effect of solvency ratios on financial} performance

Solvency Ratio (DAR) has no effect on Profitability (ROA) of cigarette sector companies listed on the IDX. From the regression results it is known that the value of $t$ count Solvability (DAR) variable is 0.224 less than $t$ table 2.03693. With a significance value of 0.810 smaller than $\alpha$ $=0.05 . \mathrm{H}^{2}$ means that $\mathrm{H}_{\mathrm{o}}$ is rejected, this indicates that the Solvability (DAR) variable has no significant effect on Profitability (ROA). This result is in line with the research conducted by Marsel Pongoh (2013) which states that the solvency ratio (DAR) has no significant effect on profitability (ROA).

\section{Effect of ratios activity to financial performance}

The Active Ratio (TATO) affects the Profitability (ROA) of the cigarette sector companies listed on the IDX. From the results of the regression it is known that the value of the activity variable $t$ count (TATO) of 3.808 is greater than the table of 2.03693. With a significant value of 0.001 smaller than $\alpha=0.05 . \mathrm{H}_{3}$ means that Ho is accepted, this shows that the Activity variable (TATO) has a significant effect on Profitability (ROA). This result is in line with research conducted by Euis Komariah (2016) which states that the solvency ratio (DAR) has a significant effect on profitability (ROA). 
Vol-2, Issue-2, 2018 (IJEBAR)

ISSN: 2614-1280, http://www.jurnal.stie-aas/ijebar

The influence of liquidity ratios, solvency ratios and activities on financial performance simultaneously

Based on the $F$ test results (simultaneous) obtained $\mathrm{F}_{\text {count }}$ of 5.381 is greater than $F_{\text {table }} 2.89$ with a significance of 0.004 smaller than the significance value of $\alpha=0.05$, so it can be concluded that simultaneously the Liquidity (CR), Solvability variables (DAR), and Activity (TATO) are factors that influences the Profitability variable (ROA) of the result of $\mathrm{F}$ test that can be seen the regression model used in this study shows the goodness of fit model.

\section{Conclusion}

(1) Liquidity (CR) does not affect the profitability of cigarette companies listed on the BEI in 2016-2018. This is evidenced by the value of $t$ count Liquidity (CR) variable of 0.552 smaller than t table 2.03693. With a significance value of 0.585 greater than $\alpha=0.05$. (2) Solvability (DAR) does not affect the profitability of cigarette companies listed on the IDX in 2016-2018. This is evidenced by the value of $t$ count Solvability (DAR) variable of 0.224 smaller than $t$ table 2.03693. With a significance value of 0.810 smaller than $\alpha$ $=0.05$. (3) Activities (TATO) affect the profitability of cigarette companies listed on the IDX 2016-2018. This is evidenced by the tcount of activity variable (TATO) of 3.808 greater than the $t$ table of 2.03693. With a significant value of 0.001 smaller than $\alpha=0.05$. (4) Liquidity (CR), Solvability (DAR), and Activity (TATO) are factors that influence the Profitability (ROA) variable of the F can be seen that the regression model used in this study shows the goodness of fit model.

\section{Suggestion}

1) It is better for the company to pay attention to the current ratio, because in the increasingly liquid manufacturing companies the company has an unfavorable influence on the return of the company's capital. To increase profitability, capital should be diverted to fixed assets so that the return received is greater. (2) It should be for investors and prospective investors, who want to invest capital owned in manufacturing companies should pay attention to the level of asset turnover and current ratio that is owned because both of these things have a significant effect on the level of return on company capital.

(3) It is better for further research to add independent variables in the research model so that the results of the research are obtained in relation to the factors that affect profitability (ROA) Can increase the number of companies or extend the period of study, so that more samples can be obtained and the number of observations that allow for better statistical results can be obtained.

\section{References}

Fahmi, I. 2011. Analisis Kinerja

Keuangan. Cetakan Kesatu. Alfabeta. Bandung.

Fahmi, I. 2012. Analisis kinerja keuangan perusahaan. Cetakan Kedua. Alfabeta. Bandung 
International Journal of Economics, Business and Accounting Research (IJEBAR)

Peer Reviewed - International Journal

Vol-2, Issue-2, 2018 (IJEBAR)

ISSN: 2614-1280, http://www.jurnal.stie-aas/ijebar

Fahmi, I. 2014. Manajemen Keuangan

Perusahaan Dan Pasar Modal. Edisi

Pertama. Mitra Wacana

Media.Jakarta.

Ghozali, Imam. (2006). Aplikasi Analisis Multivariate dengan Program SPSS, Universitas Diponegoro, Semarang.

Harahap,S.S.2013.AnalisisKritisAtasLapor anKeuangan.EdisiPertama.PT.RajaGr afindo Persada.Jakarta.

Harjito \&

Martono.2010.Manajemenkeuangan.E KONISIA.Yogyakarta.

Ikatan Akuntan Indonesia. 2012. Standart Akuntansi Keuangan. Salemba Empat. Jakarta.

Indriantoro, Nur \& Supomo, Bambang. 2002. Metodologi Penelitian Bisnis Untuk Akuntansi \& Manajemen. Edisi Pertama. BPFE: Yogyakarta

Kasmir. 2012. Analisis Laporan Keuangan. PT. Raja Grafindo Persada. Jakarta

Kasmir. 2013.AnalisisLaporanKeuangan. PT. Raja Grafindo Persada. Jakarta. Martono dan D.A.

Maith, Hendry Andreas. 2013. Analisis Laporan Keuangan Dalam Mengukur Kinerja Keuangan pada PT. Hanjaya Mandala Sampoerna Tbk. Jurnal EMBA Vol. 1 No. 3 Sepetember 2013, Hal 619-628.

Maith, Hendry Andreas. 2013. Kinerja keuangan Ditinjau Dari Analisis Rasio Keuangan. Jurnal Ekonomi Dan Bisnis, Vol.01 